\title{
The fate of amino acids in isolated perfused livers of developing sheep
}

\author{
By P. M. J. SAVAN,* MAJORIE K. JEACOCK AND D. A. L. SHEPHERD \\ Department of Physiology and Biochemistry, University of Reading, \\ Whiteknights, Reading RG6 $2 \mathrm{AJ}$
}

(Received 12 July 1978 - Accepted 17 April 1979)

\begin{abstract}
I. In order to establish whether or not there is a change in the relative rates of anabolism and catabolism of amino acids in the livers of lambs as they mature, a study has been made in isolated perfused livers obtained from foetal, suckling and ruminating lambs. The livers were perfused in a recirculating system and a mixture of amino acids (casein hydrolysate) was infused as substrate in the presence and absence of glucagon.

2. The oxygen consumption of the livers per unit weight increased as the lambs matured but the uptake of $\alpha$-amino nitrogen declined. A comparison of the rates of $\mathrm{O}_{2}$ consumption and substrate uptake indicated that in foetal lambs less than $20 \%$ of the amino acids could have been oxidized, whereas in ruminating lambs all the amino acids taken up could have been oxidized.

3. In livers obtained from foetal lambs, the rate of urea production per unit weight of liver was approximately double that observed in ruminating lambs. Comparison of the rate of urea production and $\alpha-\mathrm{NH}_{2}-\mathrm{N}$ uptake indicated that more than $60 \%$ of the substrate uptake was used for non-catabolic processes in the foetal lambs, whereas in ruminating animals all the $\alpha-\mathrm{NH}_{2}-\mathrm{N}$ taken up could be accounted for as urea.

4. Gluconeogenesis could not be detected in lambs at any age studied and glucagon had no effect on any of the parameters studied.
\end{abstract}

In adult sheep, amino acids, in addition to their role in protein synthesis, are a major source of glucose-carbon (Bergman, I973). Amino acids may also serve as a direct source of energy in adult sheep, since significant amounts of expired carbon dioxide originate from these compounds (Ford \& Reilly, 1969; Heitmann et al. 1973). The role of amino acids as a source of energy in mammals has recently been reviewed by Lindsay (1976). It is probable that amino acids entering the circulation of the developing lamb are utilized mainly for protein synthesis, due to the rapid growth of these animals, but the extent to which amino acids are used in other metabolic processes in specific organs of the developing lamb has received little attention.

The liver has a major role in the metabolism of amino acids derived from dietary protein since this organ is a site of synthesis of protein, urea and glucose. In the liver the extent of urea production relative to amino acid uptake will indicate the importance of pathways involving deamination of amino acids relative to anabolic processes such as protein synthesis. In order to find out whether or not the relative rates of these anabolic and catabolic processes change in the livers of sheep as they mature, a study has been made of the fate of a mixture of amino acids in perfused livers of foetal, suckling and ruminating lambs. Since glucagon is thought to be involved in blood amino acid homoeostasis in the sheep (Brockman \& Bergman, 1975) as in other species (Shoemaker \& van Itallie, 1960; Garrison \& Haynes, 1973), the effect of this hormone has also been studied.

* Present address: Department of Biochemistry and Agricultural Biochemistry, The University College of Wales, Penglais, Aberystwyth SY23 3DD. 
Table I. Average body-weight $(\mathrm{kg})$ and liver weight $(\mathrm{g})$ of animals used in the study

(Mean values with their standard errors)

Conceptual age $(\mathrm{d})$

I 10-I 6 (immature foetuses)

I40-I47 (mature foetuses)

I60-165 (suckling lambs)

210-2 I 5 (ruminating lambs)

255-285 (ruminating lambs)

No. of
animals
4
3
4
4
4

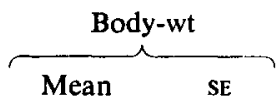

$1 \cdot 72$

$3 \cdot 86$

$6 \cdot 27$

$17 \cdot 25$

$31 \cdot 25$

\subsection{3}

$$
0.26
$$

0.41

0.14

$4 \cdot 99$

\section{EXPERIMENTAL}

Animals

Pregnant Dorset Horn ewes were tupped by either Suffolk or Dorset Horn rams on known dates in order to obtain lambs of known gestational age. Livers for perfusion were taken from animals at five different conceptual ages (d): 110-1 6 (immature foetuses); 140-147 (mature foetuses); I60-I65 (suckling lambs); 210-215 and 255-285 (ruminating lambs). Livers from foetal lambs were obtained from animals slaughtered after delivery by Caesarian section. Livers from suckling and ruminating lambs were obtained from animals slaughtered after electrical stunning. These techniques have been described previously (Edwards et al. 1975). The weights of the lambs and their livers are recorded in Table I. Heparin (approximately $1000 \mathrm{IU} / \mathrm{kg}$ ) was injected intravenously into all animals before slaughter.

\section{Perfusion technique}

The apparatus and general procedure used for liver perfusion was based on that used by Linzell et al. (197I). Immediately after slaughter of the lamb the abdomen and thorax were opened, the posterior vena cava cut just caudal to the heart and the liver flushed with icecold 0. I $54 \mathrm{M}$-sodium chloride by way of either the umbilical vein in the foetuses or the portal vein in the postnatal animals. In foetal lambs the umbilical vein and the thoracic end of the posterior vena cava were cannulated and the hepatic artery, portal vein and posterior vena cava caudal to the liver were ligated. In postnatal lambs the portal vein, hepatic artery and the thoracic end of the posterior vena cava were cannulated and the posterior vena cava caudal to the liver was ligated. In all livers the common bile duct was cannulated and the cystic duct was ligated to ensure that only freshly produced bile was collected. The liver was removed from the lamb and connected into the perfusion circuit.

Foetal livers were perfused via the umbilical vein alone, at constant volume inflow, whereas livers from postnatal animals were perfused via the hepatic portal vein at constant volume inflow and via the hepatic artery at pressures between 90 and $140 \mathrm{mmHg}$. Pressure in the venous inflow never exceeded $10 \mathrm{mmHg}$ and was frequently much lower than this.

Thus the major difference in the perfusion technique between the foetal and postnatal animals was the route of input of the perfusion medium. The difference between input by way of the umbilical vein in the foetuses and the portal vein in the postnatal animals can be disregarded since both vessels enter a common sinus from which blood is distributed throughout the organ. In the adult sheep the hepatic artery supplies up to $25 \%$ of the total hepatic blood flow (Katz \& Bergman, 1969) and hence this vessel was cannulated in the postnatal lambs. The proportion of blood supplied to the foetal liver by way of the hepatic artery is not known, but it did seem reasonable not to perfuse through the arterial circulation in the foetal preparations since it is likely that $96 \%$ of the blood supplied to the foetal liver enters by way of the umbilical and portal veins. This deduction is based on the fact that in 
the foetal lamb umbilical blood flow accounts for approximately $40 \%$ of the combined ventricular output, whereas the relative amounts of ventricular output supplying the hepatic portal circulation are only $6 \%$ (Rudolph \& Heymann, 1975). If hepatic arterial flow is approximately one-third of portal flow in the foetus as in the adult, then only $2 \%$ of the ventricular output will enter the liver by way of the hepatic artery. Therefore hepatic arterial flow in the foetus may not exceed $4 \%$ of the blood flowing into the hepatic vein.

The perfusion medium consisted of washed bovine erythrocytes resuspended to an average concentration of $290 \mathrm{ml} / \mathrm{l}$ bicarbonate buffer medium based on that of Krebs \& Henseleit (1932). The buffer contained half the calcium ion concentration of the original to approximate to the ionized $\mathrm{Ca}$ concentration of plasma, and the concentration of the bicarbonate ion was increased by approximately $40 \%$ in order to increase the buffering capacity of the medium, since no plasma protein was present. Heparin was added to the perfusate to give a final concentration of $5.0 \mathrm{IU} / \mathrm{ml}$. The medium was passed through a gas exchanger together with $\mathrm{O}_{2}, \mathrm{~N}_{2}$ and $\mathrm{CO}_{2}$. The gas flows were separately adjusted so that the $p_{\mathrm{O}_{2}}, \mathrm{PCO}_{2}$ and $\mathrm{pH}$ of the medium entering the liver were maintained at approximately $90 \mathrm{~mm} \mathrm{Hg}, 35 \mathrm{~mm} \mathrm{Hg}$ and 7.38 respectively. The medium was continuously recirculated so that metabolic changes were assessed by measuring the net accumulation or net depletion of metabolites in the system.

All livers were initially perfused for a period of $\mathrm{I} h$ in the absence of substrate, during which time the system was brought from room temperature up to $39.5^{\circ}$ for foetal liver perfusions or $38.0^{\circ}$ for postnatal lamb liver perfusions. Also, during this time the flow rate was raised to between 2.0 and $9.4 \mathrm{ml} / \mathrm{min}$ per $\mathrm{g}$ foetal liver or to between $\mathrm{I} \cdot 0$ and $3.0 \mathrm{ml} / \mathrm{min}$ per $g$ postnatal lamb liver. The faster flow rate in foetal preparations was required to maintain a positive perfusion pressure similar to that in the postnatal animals. This need for fast perfusate flow may be due to the presence of a patent ductus venosus in foetal lambs. At the end of this period the perfusate was removed and simultaneously replaced with fresh warmed oxygenated medium. This procedure removed a large proportion of glucose (derived from the breakdown of liver glycogen) from the system, thus making any subsequent changes in total carbohydrate more easily measurable. The substrate, hydrolysed casein (Koch-Light Ltd, Colnbrook, Bucks.), was then infused into the perfusate for $2 \mathrm{~h}$, and after $\mathrm{I} h$ of substrate infusion glucagon was injected to give an initial concentration of approximately $\mathrm{I} \cdot \mathrm{I} 5 \mu \mathrm{g} / \mathrm{ml}$.

During postnatal lamb liver perfusions, casein hydrolysate was infused into the circulating medium at a rate of $18.5 \mathrm{mmol} \alpha$-amino $\mathrm{N} /$ liver per $\mathrm{h}$, which is equivalent to the hepatic uptake of $\alpha-\mathrm{NH}_{2}-\mathrm{N}$ in adult sheep (Wolff et al. 1972). In foetal liver perfusions the substrate was infused at half this rate so that concentrations of $\alpha-\mathrm{NH}_{2}-\mathrm{N}$ in the perfusate were maintained at values similar to those in postnatal lamb liver perfusions.

Samples of liver tissue were taken at the beginning and at the end of each hour of perfusion and immediately clamped in tongs pre-cooled in liquid $\mathrm{N}_{2}$. These tissue portions were stored at $-70^{\circ}$ until required for analysis. The concentrations of glucose, glycogen, $\alpha-\mathrm{NH}_{2}-\mathrm{N}$ and protein were determined in these samples. In some perfusions samples of tissue were taken and dried to constant weight at $105^{\circ}$ in order to obtain the wet weight:dry weight value.

Samples of perfusate were taken from the sample ports in the portal or umbilical venous supply tube and in the vena caval outlet tube. These samples were taken at 20 min intervals throughout perfusion, and the concentrations of glucose, $\alpha-\mathrm{NH}_{2}-\mathrm{N}$, urea and protein were determined in these samples together with the $\mathrm{pH}, p_{\mathrm{CO}_{2}}, p_{\mathrm{O}_{2}}$, haemoglobin and oxyhaemoglobin contents.

Perfusate flow was measured using a purpose-built system. A diagram of this apparatus is shown in Fig. I. The outflow from the liver was allowed to flow into a Perspex cylinder 


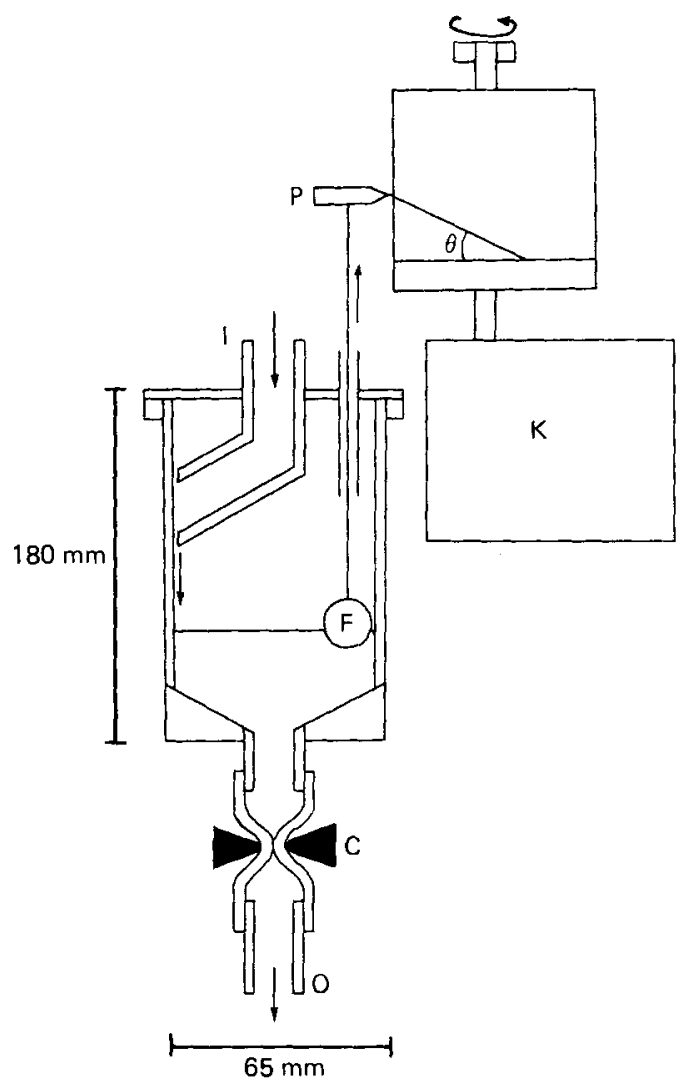

Fig. 1. Diagram of flow-meter. Perfusate from the liver flows into a Perspex cylinder through a tube (I). When the silicone-rubber tubing connecting the Perspex cylinder to the outflow (O) to the gas exchanger is occluded with a large clamp (C) the chamber fills with perfusate. In so doing, it causes a ball float $(F)$ attached to a pen (P) to rise. A kymograph $(\mathrm{K})$ is placed next to the apparatus so that its $150 \mathrm{~mm}$ diameter drum moves past the pen at $2.5 \mathrm{~mm} / \mathrm{s}$. The natural tangent of the angle $(\theta)$ is proportional to perfusate flow.

and then out into the gas exchanger. When the silicone-rubber tube connecting the Perspex cylinder to the gas exchanger was occluded, with a large clamp, the cylinder began to fill with perfusate. In so doing it caused a ball float, attached to a pen, to rise up the cylinder. A kymograph was placed next to the apparatus so that its $150 \mathrm{~mm}$ diameter drum moved past the pen at $2.5 \mathrm{~mm} / \mathrm{s}$. A calibration curve was constructed by plotting the natural tangent of the angle of the slope produced $v$. flow-rate, which was found using a measuring cylinder and stopclock. This proved to be a simple, reliable and accurate system for measuring total hepatic outflow during perfusion.

\section{Analytical procedures}

Glycogen was extracted from samples of frozen liver and precipitated with ethanol (Walaas \& Walaas, 1950). After hydrolysis the extract was neutralized and the glucose content estimated by the method of Huggett \& Nixon (1957). Other portions of freeze-clamped liver were homogenized in $20 \mathrm{vol}$. of ice-cold water. The protein contents of these liver homogenates were determined by the method of Lowry et al. (195I). The free glucose and $\alpha-\mathrm{NH}_{2}-\mathrm{N}$ contents of liver homogenates were determined after deproteinization with zinc 
sulphate and sodium hydroxide by the methods of Huggett \& Nixon (1957) and Rosen (1957) respectively. The protein content of the perfusate was determined after centrifugation to remove the erythrocytes, and the glucose and $\alpha-\mathrm{NH}_{2}-\mathrm{N}$ content determined after deproteinization of the perfusate by the methods used for liver analysis. The urea content of deproteinized samples of perfusate was determined by the method of Moore \& Kauffman (1970). The $p_{\mathrm{O}_{2}}, p_{\mathrm{CO}_{2}}$ and $\mathrm{pH}$ of the pet fusate entering and leaving the liver were measured using an IL21 3 blood gas analyser, and the concentrations of haemoglobin and oxyhaemoglobin in the perfusate were measured using an ILI82 Co-oximeter (both supplied by Instrumentation Laboratory UK Ltd, Altrincham, Cheshire).

\section{Calculations and statistical analyses}

The rate of glucose production (gluconeogenesis) or utilization per kg liver was calculated from changes in the sum of the total glycogen (expressed in terms of glucose units) and glucose content of the liver and the glucose content of the perfusate obtained at intervals. The change in protein in the whole system was calculated from the sum of the total liver protein plus the protein content of the erythrocyte-free perfusate (corrected for haemolysis). The rate of uptake of $\alpha-\mathrm{NH}_{2}-\mathrm{N}$ was calculated from a knowledge of the substrate infusion rate (Unita II precision syringe pump; B. Braun Melsungen AG, F.T. Scientific Instruments Ltd, Bredon, Tewkesbury, Glos.) and the amount in the circulation. The rate of urea production was calculated from the urea concentration and the total volume of the perfusate.

$\mathrm{O}_{2}$ consumption was calculated from the product of the total perfusate flow-rate and the difference between the $\mathrm{O}_{2}$ content of the perfusate entering and leaving the liver. $\mathrm{O}_{2}$ content is the sum of the dissolved $\mathrm{O}_{2}$ and $\mathrm{O}_{2}$ bound to haemoglobin. Dissolved $\mathrm{O}_{2}(\mathrm{ml} / \mathrm{l}$ perfusate) was obtained by multiplying the $p_{2}$ by 0.03 assuming the solubility of oxygen in water is $0.03 \mathrm{ml} / 1$ per $\mathrm{mmHg}$. $\mathrm{O}_{2}$ bound to haemoglobin per I perfusate was calculated using the following expression: bound $\mathrm{O}_{2}=$ (haemoglobin $(\mathrm{g} / \mathrm{l}) \times$ oxyhaemoglobin/ $\left./ 100\right) \times \mathbf{I} 34$. This assumes that $\mathrm{I} g$ haemoglobin can combine with $\mathrm{I} \cdot 34 \mathrm{ml} \mathrm{O}_{2}$. The $\mathrm{O}_{2}$ consumption of individual preparations during the two periods in which substrate was infused in the absence of glucagon and in the presence of glucagon was the mean of the three measurements made in each period.

The significance of differences between means of groups of values was assessed by analysis of variance.

\section{Viability of the preparation}

The viability of the preparation was assessed by considering several parameters. Liver wet weight:dry weight values were measured at intervals during several perfusions and were found to remain constant. This is important, since oedematous congestion of the liver caused by a net gain of water would have led to the interruption of blood flow and subsequent damage to the cells. As there was no significant change in the water content of the liver during perfusion the presentation of the results in terms of liver wet weight would appear valid. A satisfactory preparation viable throughout the course of perfusion would also be expected to maintain constant rates of $\mathrm{O}_{2}$ consumption, bile production and urea production whilst supplied with substrate. The results reported in this paper were obtained from perfused livers which met these criteria. For a typical ruminating lamb liver the rate of $\mathrm{O}_{2}$ consumption $(\mu \mathrm{mol} / \mathrm{kg}$ per min; $C$ ) is described by the equation $C=0.49 x+995$ $(r 0.096)$ where $x$ is the period of time ( $\mathrm{min}$ ) from the start of infusion of substrate. Thus there was no significant change in the rate of $\mathrm{O}_{2}$ consumption with time. The amount of urea $(\mathrm{mmol} ; U)$ present in the perfusate increased linearly with perfusion time: $U=0.0335 x+\mathrm{I} \cdot \mathrm{OI}(r 0.974)$ and the volume of bile $(\mathrm{ml} ; B)$ collected during perfusion also increased linearly with time: $B=0.032 x+0.19\left(\begin{array}{l}r \\ 0.995)\end{array}\right)$. 
Table 2. The effect of conceptual age on the rates of oxygen consumption ( $\mu \mathrm{mol} / \mathrm{kg}$ wet weight liver per min) by lamb livers perfused in the absence of added substrate, in the presence of casein hydrolysate* and in the presence of casein hydrolysate and glucagon $\dagger$

(Mean values with their standard errors)

Conceptual age (d)

I IO-I I6 (immature foetuses)

I40-147 (mature foetuses)

I60-165 (suckling lambs)

2 $10-2$ i 5 (ruminating lambs)

255-285 (ruminating lambs)

\begin{tabular}{|c|c|c|c|c|c|c|}
\hline \multirow{3}{*}{$\begin{array}{c}\text { No. of } \\
\text { perfusions }\end{array}$} & \multicolumn{6}{|c|}{$\mathrm{O}_{2}$ consumption } \\
\hline & \multicolumn{2}{|c|}{$\begin{array}{l}\text { No added } \\
\text { substrate }\end{array}$} & \multicolumn{2}{|c|}{$\begin{array}{l}\text { In presence } \\
\text { of casein } \\
\text { hydrolysate }\end{array}$} & \multicolumn{2}{|c|}{$\begin{array}{c}\text { In presence } \\
\text { of casein } \\
\text { hydrolysate and } \\
\text { glucagon }\end{array}$} \\
\hline & Mean & SE & Mean & SE & Mean & SE \\
\hline 4 & 300 & 135 & 543 & 141 & 484 & 196 \\
\hline 3 & 388 & 179 & 646 & I I I & $73 I$ & 196 \\
\hline 4 & 330 & $8 \mathrm{I}$ & 607 & 59 & 689 & 60 \\
\hline 4 & 285 & 10 & 873 & 45 & 927 & 37 \\
\hline 4 & 304 & 17 & 1006 & 50 & 1105 & 91 \\
\hline
\end{tabular}

* Casein hydrolysate substrate was infused at 18.5 and $9.25 \mathrm{mmol} \alpha$-amino-nitrogen/liver per $h$ in postnatal and foetal lamb liver perfusions respectively.

$\dagger$ The initial concentration of glucagon was approximately $1 \cdot 15 \mu \mathrm{g} / \mathrm{ml}$.

Table 3. The effect of conceptual age on the rates of uptake of $\alpha$-amino-nitrogen ( $\mu m o l / k g$ wet weight liver per min) and urea production (umol/kg wet weight liver per min) by lamb livers perfused in the presence of casein hydrolysate* and in the presence of casein hydrolysate and glucagon $\dagger$

(Mean values with their standard errors)

\begin{tabular}{|c|c|c|c|c|c|c|c|c|c|}
\hline \multirow[b]{3}{*}{ Conceptual age (d) } & \multirow{3}{*}{$\begin{array}{c}\text { No. of } \\
\text { perfusions }\end{array}$} & \multicolumn{4}{|c|}{$\alpha-\mathrm{NH}_{2}-\mathrm{N}$ uptake } & \multicolumn{4}{|c|}{ Urea production } \\
\hline & & \multicolumn{2}{|c|}{$\begin{array}{l}\text { In presence } \\
\text { of casein } \\
\text { hydrolysate }\end{array}$} & \multicolumn{2}{|c|}{$\begin{array}{c}\text { In presence } \\
\text { of casein } \\
\text { hydrolysate and } \\
\text { glucagon }\end{array}$} & \multicolumn{2}{|c|}{$\begin{array}{l}\text { In presence } \\
\text { of casein } \\
\text { hydrolysate }\end{array}$} & \multicolumn{2}{|c|}{$\begin{array}{c}\text { In presence } \\
\text { of casein } \\
\text { hydrolysate and } \\
\text { glucagon }\end{array}$} \\
\hline & & Mean & SE & Mean & SE & Mean & SE & Mean & SE \\
\hline $\begin{array}{l}\text { r Io-1 I6 } \\
\quad \text { (immature foetuses) }\end{array}$ & 4 & 1396 & 208 & 914 & 44 & 240 & 43 & 163 & 57 \\
\hline $\begin{array}{l}140-147 \\
\text { (mature foetuses) } \\
160-165\end{array}$ & 3 & 696 & 155 & 986 & 176 & 238 & 23 & 199 & 36 \\
\hline (suckling lambs) & 4 & 238 & 121 & 336 & 138 & $12 I$ & 24 & 192 & 37 \\
\hline $\begin{array}{l}210-215 \\
\text { (ruminating lambs) } \\
255-285\end{array}$ & 4. & 238 & 30 & 289 & $2 I$ & 102 & 17 & 81 & II \\
\hline (ruminating lambs) & 4 & I 4 I & 16 & 209 & 44 & 121 & 14 & 134 & 13 \\
\hline
\end{tabular}

* Casein hydrolysate substrate was infused at 18.5 and $9.25 \mathrm{mmol} \alpha-\mathrm{NH}_{2}-\mathrm{N} / \mathrm{liver}$ per $\mathrm{h}$ in postnatal and foetal lamb liver perfusions respectively.

$\dagger$ The initial concentration of glucagon was approximately $I \cdot I 5 \mu \mathrm{g} / \mathrm{ml}$.

\section{RESULTS}

The mean rates of $\mathrm{O}_{2}$ consumption by perfused livers obtained from lambs at five different ages are shown in Table 2 . In the absence of added substrate there was no difference in the $\mathrm{O}_{2}$ consumption expressed per $\mathrm{kg}$ liver between the lambs of different ages. The most substantial increase in $\mathrm{O}_{2}$ consumption which occurred when substrate was infused was 


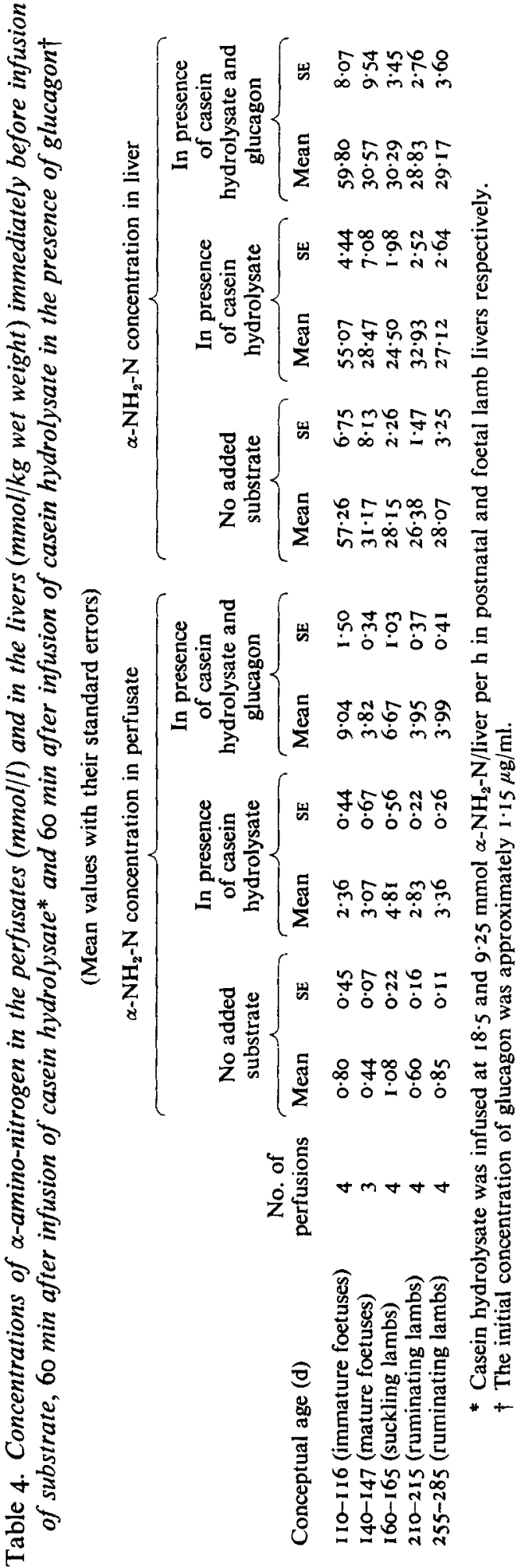


observed in livers obtained from ruminating lambs. In the presence of casein hydrolysate there was a significant increase in $\mathrm{O}_{2}$ consumption with age $(P<0.001)$ but glucagon had no additional effect on this parameter. Table 3 shows the mean rates of uptake of $\alpha-\mathrm{NH}_{2}-\mathrm{N}$ by the livers. This indicates that with the exception of the immature foetuses, glucagon had no significant effect on substrate uptake, and that there was a significant decline in substrate uptake as the lambs matured $(P<0.00 \mathrm{I})$. The concentration of $\alpha-\mathrm{NH}_{2}-\mathrm{N}$ in the perfusate just before infusion of substrate, $60 \mathrm{~min}$ after infusion of casein hydrolysate and a further $60 \mathrm{~min}$ after infusion of casein hydrolysate in the presence of glucagon are shown in Table 4. It is evident that there was no relationship between the rate of uptake and the concentration of $\alpha-\mathrm{NH}_{2}-\mathrm{N}$ in the perfusate. The concentrations of $\alpha-\mathrm{NH}_{2}-\mathrm{N}$ in the liver tissue were also determined during each perfusion (Table 4). At no age did $\alpha-\mathrm{NH}_{2}-\mathrm{N}$ accumulate in the livers throughout the period of perfusion despite its appreciable rates of uptake, especially by the livers from the younger animals. However, the mean concentration was significantly higher $(P<0.00 \mathrm{I})$ in livers from the immature foetal lambs than at any other age.

The mean rates of urea production by the perfused livers are shown in Table 3 . The rates of urea production declined significantly $(P<0.05)$ with increasing age of animal. Glucagon had no significant effect on the rates of urea production at any age. The protein content of the perfusion system was variable, but no net change in total protein content was detected in either the presence or absence of glucagon. Similarly no significant net carbohydrate production or utilization was demonstrated.

\section{DISCUSSION}

It may be presumed that the rate of uptake of $\alpha-\mathrm{NH}_{2}-\mathrm{N}$ by the livers represented the rate of utilization since there was no accumulation of amino acids in the liver during the course of a perfusion. The fact that $\alpha-\mathrm{NH}_{2}-\mathrm{N}$ concentration in the immature foetal livers was considerably greater than that in other groups studied is in accord with observations on the free amino acid concentration in foetal and adult human liver (Ryan \& Carver, 1966).

In a study of hepatic metabolism in adult Soay Sheep, Linzell et al. (I97I) found that $\mathrm{O}_{2}$ uptake of livers perfused with casein hydrolysate and propionic acid ranged from $I \cdot 2 \mathrm{I}-\mathrm{I} \cdot 62$ $\mathrm{mmol} / \mathrm{kg}$ liver per min depending upon the type of preparation. These values may be compared with the mean $\mathrm{O}_{2}$ uptake by the livers of ruminating lambs in this study which was $1.07 \mathrm{mmol} / \mathrm{kg}$ liver per min. Taken together these results may indicate that hepatic $\mathrm{O}_{2}$ consumption in the presence of amino acids increases with increasing age.

Despite the increased $\mathrm{O}_{2}$ consumption by the liver as the lamb ages the uptake of $\alpha-\mathrm{NH}_{2}-\mathrm{N}$ decreased during the same period of development. The ratio, $\mathrm{O}_{2}$ uptake to $\alpha-\mathrm{NH}_{2}-\mathrm{N}$ uptake, exceeded 6 for the older ruminating lambs studied but was less than I for both groups of foetal lambs (Table 5). The amount of $\mathrm{O}_{2}$ which is consumed when an amino acid is converted to urea, $\mathrm{CO}_{2}$ and water may be calculated from knowledge of established metabolic pathways. For example the catabolism of I mol alanine in the perfused liver may be expected to be associated with the uptake of $3 \mathrm{~mol} \mathrm{O}_{2}$ and $\mathrm{I}$ mol glutamate with 4.5 mol $\mathrm{O}_{2}$. It is apparent therefore that the $\mathrm{O}_{2}$ uptake in the livers of mature ruminating lambs is adequate to account for the complete oxidation of the amino acids taken up from the perfusate. In the immature foetuses less than $20 \%$ of the amino acids taken up from the perfusion medium could have been oxidized. That amino acids are oxidized in foetal lambs is supported by the studies of Gresham et al. (1972), which indicated that amino acid catabolism may account for up to $25 \%$ of the $\mathrm{O}_{2}$ consumption of the ovine foetus in utero.

If amino acid oxidation occurs then the $\mathrm{N}$ must be disposed of, and the most probable fate for this $\mathrm{N}$ in the liver is urea. The present study indicates that urea production per unit 
Table 5. The effect of conceptual age on the ratio, oxygen consumption: $\alpha$-amino-nitrogen uptake and urea production: $\alpha-\mathrm{NH}_{2}-\mathrm{N}$ uptake in lamb livers perfused in the presence of casein hydrolysate* and in the presence of casein hydrolysate and glucagon $\dagger$

(Mean values with their standard errors)

\begin{tabular}{|c|c|c|c|c|c|c|c|c|c|}
\hline \multirow[b]{4}{*}{ Conceptual age (d) } & \multirow{4}{*}{$\begin{array}{l}\text { No. of } \\
\text { perfusions }\end{array}$} & \multirow{2}{*}{\multicolumn{4}{|c|}{$\underbrace{\mathrm{O}_{2} \text { consumption }}_{\alpha-\mathrm{NH}_{2}-\mathrm{N} \text { uptake }}$}} & \multirow{2}{*}{\multicolumn{4}{|c|}{$\overbrace{\alpha-\mathrm{NH}_{2}-\mathrm{N} \text { uptake }}^{\text {Urea production }}$}} \\
\hline & & & & & & & & & \\
\hline & & \multicolumn{2}{|c|}{$\begin{array}{l}\text { In presence } \\
\text { of casein } \\
\text { hydrolysate }\end{array}$} & \multicolumn{2}{|c|}{$\begin{array}{c}\text { In presence } \\
\text { of casein } \\
\text { hydrolysate and } \\
\text { glucagon }\end{array}$} & \multicolumn{2}{|c|}{$\begin{array}{l}\text { In presence } \\
\text { of casein } \\
\text { hydrolysate }\end{array}$} & \multicolumn{2}{|c|}{$\begin{array}{c}\text { In presence } \\
\text { of casein } \\
\text { hydrolysate and } \\
\text { glucagon }\end{array}$} \\
\hline & & Mean & $\mathbf{S E}$ & Mean & SE & Mean & SE & Mean & SE \\
\hline $\begin{array}{l}\text { I Io-1 I } 6 \\
\text { (immature foet uses) }\end{array}$ & 4 & 0.42 & 0.14 & 0.56 & 0.25 & 0.19 & 0.06 & 0.19 & 0.07 \\
\hline $\begin{array}{l}\text { I40-1 } 147 \\
\text { (mature foetuses) } \\
\text { I } 60-165\end{array}$ & 3 & $\mathrm{I} \cdot 07$ & 0.34 & 0.83 & 0.10 & 0.37 & 0.08 & 0.23 & 0.08 \\
\hline (suckling lambs) & 4 & $2 \cdot 64$ & I'34 & $2 \cdot 49$ & $1 \cdot 43$ & 0.57 & 0.17 & 0.93 & 0.30 \\
\hline $\begin{array}{l}210-2 \text { is } \\
\text { (ruminating lambs) } \\
255^{-285}\end{array}$ & 4 & $3 \cdot 8 \mathrm{I}$ & 0.44 & $3 \cdot 26$ & $0 \cdot 26$ & 0.48 & 0.13 & 0.29 & 0.06 \\
\hline (ruminating lambs) & 4 & $7 \cdot 54$ & 1.08 & $6 \cdot 35$ & $1 \cdot 71$ & 0.87 & 0.07 & 0.72 & $0 \cdot I \mathrm{I}$ \\
\hline
\end{tabular}

weight of liver declines as the lamb matures, and from this observation it can be inferred that the amount of amino acid deaminated decreases with age. However, it is appropriate to consider the relationship between the rate of $\alpha-\mathrm{NH}_{2}-\mathrm{N}$ uptake and urea production. Values for the ratio of these parameters are shown in Table 5. Since I mol urea could be derived from $2 \mathrm{~mol} \alpha-\mathrm{NH}_{2}-\mathrm{N}$ it would appear that less than $40 \%$ of the substrate taken up is converted to urea in the immature foetus whilst in the fully ruminating lamb all the $\alpha-\mathrm{NH}_{2}-\mathrm{N}$ taken up could have been converted to urea. The $\alpha-\mathrm{NH}_{2}-\mathrm{N}$ taken up and which could not be accounted for as urea must have been used for non-catabolic processes, and in the immature foetal livers at least $60 \%$ of the $\alpha-\mathrm{NH}_{2}-\mathrm{N}$ taken up must have been used in this manner. This value obtained for the isolated liver may be compared with the results of Gresham et al. (1972) who showed that only $60 \%$ of the $\mathrm{N}$ crossing the placenta is retained by the entire foetus for growth.

No change in the total protein of the liver and perfusate was detected during perfusion of livers. This is perhaps not surprising, since it is unlikely that a change in protein content resulting from the infusion of approximately $\mathrm{I} .8 \mathrm{~g}$ mixed amino acids $/ \mathrm{h}$ would be evident, since the total average protein content of the perfusion system was initially $20.02 \pm \mathrm{I} \cdot 70 \mathrm{~g}$ in perfusions of foetal liver. It must also be noted that the use of casein hydrolysate as substrate may not provide a balanced input of the essential amino acids and in particular the low tryptophan content could limit protein synthesis in this preparation.

The finding that there was no gluconeogenesis occurring in the perfused livers in the presence of casein hydrolysate and glucagon at any age was unexpected since amino acids are major substrates for gluconeogenesis in adult sheep, alanine and glutamate being predominant (Wolff et al. 1972). Whereas casein hydrolysate contains a relatively low content of alanine, the content of glutamic acid is appreciable (Haryey, I956). Using the same 
perfusion technique with alanine, lactate or propionate as the infused substrate, gluconeogenesis has been shown to occur in the presence of glucagon in foetal and suckling lambs (Savan et al. 1976). It is unlikely, therefore, that the failure of the livers to synthesize glucose when provided with casein hydrolysate could be attributed to a non-viable preparation. In this context it is perhaps relevant to note that Mallette et al. (1969) were able to demonstrate an increase in glucose production in perfused rat liver from a mixture of amino acids when using a non-recirculating system. The possibility exists that in a recirculating system as used by us, inhibitors of gluconeogenesis formed from certain amino acids accumulate during perfusion, and this may be the reason why gluconeogenesis was not demonstrated in this study.

Thus it is evident that as the lamb matures the hepatic uptake of amino acids per unit weight of liver declines. However, the proportion of amino acids taken up which is deaminated and subsequently oxidized is considerably greater in ruminating lambs compared with foetal lambs.

\section{REFERENCES}

Bergman, E. N. (1973). Cornell Vet. 63, 34I.

Brockman, R. P. \& Bergman, E. N. (1975). Am. J. Physiol. 228, 1627.

Edwards, E. M., Dhand, U. K., Jeacock, M. K. \& Shepherd, D. A. L. (1975). Biochim. Biophys. Acta 399, 219.

Ford, E. J. H. \& Reilly, P. E. B. (1969). Res, vet. Sci. 10,, 409.

Garrison, J. C. \& Haynes, R. C. (I973). J. biol. Chem. 248, 5333.

Gresham, E. L., James, E. J., Raye, J. R., Battaglia, F. C., Makowski, E. L. \& Meschia, G. (1972). Pediatrics, Springfield 5o, 372.

Harvey, D. (1956). Tech. Bull. Commonw. Bur. Anim. Nutr. no. 9.

Heitmann, R. N., Hoover, W. H. \& Sniffen, C. J. (1973). J. Nutr. 103, 1587.

Huggett, A. St G. \& Nixon, D. A. (1957). Lancet ii, 368.

Katz, M. L. \& Bergman, E. N. (1969). Am. J. Physiol. 216, 946.

Krebs, H. A. \& Henseleit, K. (1932). Hoppe-Seyler's Z. physiol Chem. 210, 33.

Lindsay, D. B. (1976). In Protein Metabolism and Nutrition, p. 183 [D. J. A. Cole, K. N. Boorman, P. J. Buttery, D. Lewis, R. J. Neale and H. Swan, editors]. London: Butterworths.

Linzell, J. L., Setchell, B. P. \& Lindsay, D. B. (I97I). Q. Jl. exp. Physiol. 56, 53.

Lowry, O. H., Rosebrough, N. J., Farr, A. L. \& Randall, R. J. (1951). J. biol. Chem. 193, 265.

Mallette, L. E., Exton, J. H. \& Park, C. R. (1969). J. biol. Chem. 244, 57ı3.

Moore, R. B. \& Kauffman, N. J. (1970). Analyt. Biochem. 33, 263.

Rosen, H. (1957). Archs Biochem Biophys. 67, 10.

Rudolph, A. M. \& Heymann, M. A. (I975). In The Mammalian Fetus, p. 5 [E. S. E. Hafez, editor]. Springfield, Ill.: C. C. Thomas.

Ryan, W. L. \& Carver, M. J. (1966). Nature, Lond. 212, 292.

Savan, P. M. J., Jeacock, M. K. \& Shepherd, D. A. L. (1976). Proc. Nutr. Soc. 35, 30 A.

Shoemaker, W. C. \& van Itallie, T. B. (1960). Endocrinology 66, 260.

Walaas, O. \& Walaas, E. (1950). J. biol. Chem. 187, 769.

Wolff, J. E., Bergman, E. N. \& Williams, H. H. (1972). Am. J. Physiol. 223, 438. 